\title{
SALMOND, NECESSITY, AND THE STATE
}

\author{
Alex Frame*
}

This article explores the varying approaches of Sir John Salmond as government adviser, judicial office, and legal theorist, to the State and the circumstances under which it might act under "necessity" in disregard of law. An epilogue provides the writer's own attempt in formal advice to delineate the boundaries of the doctrine in modern jurisprudence.

"Wrest once the law to your authority: To do a great right, do a little wrong."

Bassanio, in Shakespeare's Merchant of Venice, Act IV, Scene 1

\section{INTRODUCTION}

Shakespeare has captured in a flash the great justification for "State Necessity", often given its French label of "Raison d'Etat": the claim that "necessity" may require the State to act in disregard of law, in a "meta-legal" posture. ${ }^{1}$ The doctrine's seductiveness is there too; surely we don't want bad people to overwhelm our country and our cherished values by stealth and crime while our authorities dither over legal niceties? Just a little illegality to see us through to victory in the cause of a greater good?

Oliver Cromwell, who knew something of such matters, saw the dangers: "Necessity hath no law. Feigned necessities, imaginary necessities ... are the greatest cozenage that men can put upon the Providence of God, and make pretence to break known rules by."2

William Pitt told the House of Commons on 18 November 1783 that "[n]ecessity is the plea for every infringement of human freedoms. It is the argument of tyrants; it is the creed of slaves."3

* University of Waikato.

1 The French term needs to be approached with caution, having shifted in meaning across time, as pointed out by Sir Herbert Butterfield "Raison d'Etat: the Relations between Morality and Government" (First Martin Wight Memorial Lecture, University of Sussex, 1975).

2 Oliver Cromwell (1599-1658), apparently on 12 September 1654, according to the Oxford Dictionary of Quotations (2 ed, Oxford University Press, London, 1953) 167. "Cozen" means to cheat or defraud.

3 William Pitt (1759-1806), quoted in Oxford Dictionary of Quotations, ibid, 379. 
The purpose of this paper is to explore the place and role of the State in Sir John Salmond's legal philosophy. In particular, I propose to assess Salmond's view of the question whether, and when, the State and its officials might be justified, or excused, in taking action in disregard of the law. Our evidence must include not only the famous jurist's writings on the subject, but also his actions as a high officer of the State and a judge. Finally, the paper considers a highly theoretical question with unsuspected practical consequences: does the defence of "necessity" involve the claim that the necessitated action is lawful, or does it merely claim that, although "unlawful", it is redeemed by circumstance so as not to be "wrongful"?

A question I have put to first-year law classes over the years is: what should a State official, with no power to search without warrant, do on receiving a tip-off by cell-phone that a person before him is carrying a bomb and intending to detonate it in a nearby crowd? Nowhere near as imaginative as Lon Fuller's "Speluncean Explorers", but serviceable enough. Is it to be fiat justitia ruat coelum uphold the letter of the law even if the world blows up? Or should it be salus populi suprema lexthe safety of the people is the supreme law?

I suppose the right answer is that we should make sure that sufficient but reviewable powers are available to officials to reconcile the two principles of legality and necessity, and no doubt most legal systems will have my simple example covered. But more challenging examples can be conceived - at both domestic and, as historical and current world events tragically demonstrate, international levels.

Friedrich Meinecke, writing in Weimar Germany, put the State-leader's dilemma in this way: ${ }^{4}$

If a statesman feels himself obliged by "necessity of State" to violate law and ethics, he can still feel himself morally justified at the bar of his own conscience, if in doing so he has, according to his own personal convictions, thought first of the good of the State entrusted to his care ... Thus all conduct prompted by raison d'etat fluctuates continuously back and forth between light and dark.

Meinecke again - in 1925, to give prophecy its due - contrasting two philosophical tendencies: ${ }^{5}$

The profound shortcoming of the Western mode of thought (on the lines of natural law) was that, when applied to real State life, it remained a mere dead letter; it did not affect the statesman deeply, it did not hinder the modern hypertrophy of raison d'etat ... The profound shortcoming in German historical thought was its tendency to excuse and idealise power politics by the doctrine that it accorded with a superior type of morality.

4 Friedrich Meinecke Machiavellism: The Doctrine of Raison d'Etat and its Place in Modern History (trans Douglas Scott, Yale University Press, New Haven, 1962) 6. The work was first published in German in 1925.

5 Ibid, 426. 
In delivering the first Martin Wight Memorial in 1975, Sir Herbert Butterfield spoke of Cardinal Richelieu as a great exponent of "raison d'Etat": ${ }^{6}$

Richelieu called forth out of the idea of the state, out of raison d'etat itself, the powers that the body politic could be conceived to carry in the last resort. Over and over again it was the idea of the state that was used to validate the action, the trampling on vested interests and existing rights. But he went further than that - he even broke his own rules and he stated his regrets later - pleading the extremity of the emergency or the need for rapid action for example.

\section{SALMOND'S GENERAL VIEW OF THE STATE}

This could not be the place to trace the development of the concept of the "State" in Western thought as an abstract embodiment of the underlying constitutional structure and social order. Professor Powicke's 1936 address to the Royal Historical Society offers this observation: ${ }^{7}$

Now, behind all this we have the consciousness of a living, changing, yet continuous society, of a society which does not depend on individual caprice, does not die, and has its own "state" and traditions. This quality in feudal society impressed the Moslem world as soon as the Latin states of Syria were established. When Jocelin of Courtenay, Count of Edessa, was captured in 1122, he was offered his freedom on condition of surrendering his county. An Arab historian records his reply: "We are like laden camels; when one falls, the baggage is transferred to another; our possessions have already passed to other hands"

More prosaically, Salmond defined the State as "a society of men established for the maintenance of peace and justice within a determined territory by way of force". ${ }^{8}$ We should begin by reviewing Salmond's concept of law and noting the ontological priority he gave to constitutional fact over constitutional law: "The constitution as a matter of fact is logically prior to the constitution as a matter of law ... Constitutional law followed hard upon the heels of constitutional fact". ${ }^{9}$

This dictum will be found cited - often coupled with Kelsen's doctrine of the "grundnorm" 10 _ by courts trying to bridge the chasm between a displaced constitutional régime and its effective usurper. See, for example, Munir CJ's judgment in the 1958 Pakistan case of State $v$ Dosso: ${ }^{11}$

6 Butterfield, above n 1, 16.

7 FM Powicke "Reflections on the Medieval State" (Presidential Address, Royal Historical Society, London, 13 February 1936) in (1936) XIX Transactions of the Royal Historical Society 4th Ser 1, 15-16.

8 Sir John Salmond Jurisprudence (7 ed, Sweet \& Maxwell, London, 1924) 145.

$9 \quad$ Ibid, 154-155.

10 Itself owing something to Salmond's "ultimate legal principle" as I have suggested in Alex Frame Salmond: Southern Jurist (Victoria University Press, Wellington, 1995) 66-67.

11 State v Dosso [1958] 1 PLD 533, 538 (Pak SC) Munir CJ. 
If the revolution is victorious in the sense that the persons assuming power under the change can successfully require the inhabitants of the country to conform to the new regime, then the revolution itself becomes a law-creating fact because thereafter its own legality is judged not by reference to the annulled Constitution but by reference to its own success ...

Similarly, in Mokotso v HM King Moshoeshoe II, Cullinan CJ cites Salmond's "hard upon the heels" observation to support the legal efficacy of an obedience-commanding usurpation. ${ }^{12}$

In fairness to Salmond's fact-based concept of legitimacy, it should be noted that he did not regard that as the only relevant consideration: ${ }^{13}$

It does not follow that because the legal title of a successful usurper of sovereign power is, by reason of his success, as good as if he had been lawful heir to the sovereignty, there is no difference between lawful and lawless succession.

Interestingly, more recently we find a developing judicial tendency to require a more complete and free demonstration of public support for a usurping regime, in cases such as Mitchell from the Caribbean in 1986 and, closer to home, the Prasad case from Fiji in 2000. ${ }^{14}$

In the Prasad case, Justice Gates upheld the 1997 Constitution of Fiji against the coup of 19 May 2000 and its aftermath. But although the coup did not succeed in displacing the Constitution, the learned Judge did recognise that in an emergency, "necessity" might warrant extraordinary measures: ${ }^{15}$

In cases of real emergency the maxim "salus populi est suprema lex" applies (that is the welfare of the people is the paramount law). Oliver Cromwell, who had briefly studied law at Lincoln's Inn but who had probably gained his directness and common sense from farming in Cambridgeshire, allegedly said: "If nothing should be done but what is according to law, the throat of the nation might be cut while we send for someone to make a law". I am satisfied that the President acted as lawfully as he could in the circumstances, that he acted under the doctrine of necessity and that he acted in an attempt to buttress the lawful framework of the state.

The Prasad case went on to the Court of Appeal of Fiji where Sir Maurice Casey P also accepted that the "necessity" created by the hostage-taking of Ministers in Parliament was available to "validate" actions not authorised by the Constitution, but not to abrogate the Constitution. ${ }^{16}$ As to

12 Mokotso v King Moshoeshoe II [1989] LRC (Const) 24, 90 (Lesotho HC) Cullinan CJ.

13 Sir John Salmond The First Principles of Jurisprudence (Stevens and Haynes, London, 1893) 138-139.

14 Mitchell v Director of Public Prosecutions [1986] LRC (Const) 35 and Prasad v Republic of Fiji [2001] 1 LRC 665 (HC).

15 Prasad, ibid, 684 Gates J.

16 Republic of Fiji v Prasad [2001] 2 LRC 743, 762 (CA) Casey P. 
the proper test for determining whether there had been an effective replacement of the previous legal order, the Court adopted an approach similar to that in Mitchell, in particular requiring that there be "popular acceptance as opposed to mere tacit acquiescence". ${ }^{17}$ This reminds us that the resort to "necessity" is not always ignoble and that "raison d'état" is not always the pretext of the dictator. Sometimes the doctrine is called in aid to protect legitimacy from the usurper.

It must be faced that one of the dangers of that line of legal philosophy, which includes Hobbes, Bentham, and Austin - sometimes dubbed "the imperative theory of law"- is its tendency to elevate the law-giver beyond legal obligation. This follows from the rigidity of the definitional requirement that the legal power of the "sovereign" be incapable of legal limitation - if it could be limited, the purists argued, then we would have to look elsewhere for the true "sovereign". Salmond stated his own position in relation to that theory in this way: ${ }^{18}$

[T]hough it falls short of an adequate analysis, it undoubtedly expresses a very important aspect of the truth. It rightly emphasises the central fact that the civil law is based on the will and physical force of the organised political community. Such law exists only as an incident of the administration of justice by the state, and this consists essentially in the imperative and coercive action of the state in imposing its will, by force if need be, upon the members of the body politic.

The Hobbesian "sovereign" was the source of law but, as a matter of definition, not itself subject to the laws of which it was creator. Salmond's dictum that the State "is a corporate body whose function is the maintenance of right by might"19 must be admitted to have a Hobbesian whiff about it. The "meta-legal" character of the State seems embedded in the Salmondian view of law. Indeed, he wrote explicitly that "[t]he redress by the State of injuries inflicted by itself on its subjects ... is not the administration of justice, for the element of physical force is wanting: and therefore ... the State can have no legal duties". ${ }^{20}$ So the State is not seen by Salmond as "subject" to its own laws, even when it condescends to grant redress in respect of injuries inflicted by it.

When these views on the place of the State in legal theory are considered alongside Salmond's apparent political preference for an actively authoritarian state, it will be understood why his writings have sometimes been treated with suspicion by generations after World War II. Salmond's

17 Ibid, 770, Casey P.

18 Salmond Jurisprudence, above n 8, 22.

19 Salmond First Principles of Jurisprudence, above n 13, 118. See Frame Salmond: Southern Jurist, above n 10,48 .

20 Salmond First Principles of Jurisprudence, ibid, 136-137. 
1920 letter to Lord Bryce tells us something of our jurist's view of the proper relationship between State and subject: ${ }^{21}$

What strikes me as the characteristic feature of a colonial democratic government is its extraordinary weakness. It lives by and depends on every breath of popular favour. To exist it must conciliate, compromise, and give way. There is no real force at the back of it, and the State exists not to govern men but to give them what they ask for ... I thought at one time that the military discipline of the war would have the result of infusing through the community a greater sense of orderly subordination to the State and its laws. So far, however, I see little sign of such change ...

This is not the sort of stuff calculated to appeal to the Council for Civil Liberties. A word of caution is needed, however. "Libertarianism" seems a fickle sentiment in New Zealand's history. Demands today that the State withdraw from this or that activity are likely to be overtaken tomorrow by indignant questions of the "what is the gu'ment doing about it?" variety.

In 1910, Sir John Findlay, Attorney-General of New Zealand in Salmond's time, explicitly rejected John Stuart Mill's "very simple principle" - that coercion of the individual by the State is only justified by the prevention of harm to others. ${ }^{22}$ The tone and content of that address in Palmerston North tell us much about the attitude of Edwardian New Zealand liberals towards the role of the State. Findlay's State was frankly bossy, impatient of Mill's "individualism", and determined to get on with the job of "improving" citizens, whether they liked it or not. The Attorney-General wheeled up his friend Professor Salmond's proto-Hohfeldian analysis to demonstrate that "rights" were a concession to the citizen by the State, to be granted or withheld in accordance with utilitarian calculus.

Salmond, the lapsed "son of the manse", in his whimsical and privately published book of sayings ventured that: "Since all our beliefs as to the nature of the universe are probably mere illusions, there is much to be said in favour of accepting any creed that makes us happier than we should be without it". ${ }^{23}$ Could it be that for Salmond and his contemporary "free-thinkers", the State had replaced God as the transcendent unifying force?

21 Salmond to Lord Bryce, 24 February 1920, from Bryce Papers (Bodleian Library, Oxford), transcribed and quoted in full in Frame Salmond: Southern Jurist, above n 10, 224.

22 Hon Dr John Findlay KC "Legal Liberty" (Lecture to the Philosophical Society, Palmerston North, 21 April 1910) in New Zealand Times Wellington.

23 'My Son' Said the Philosopher: Being the Meditations of the Late Epaphroditus McTavish, privately published by Sir John Salmond, 1920. 


\section{SALMOND IN THEORY - "NECESSITY" AS A DEFENCE}

As to the doctrine of "necessity" generally, we must start by observing Salmond's approach to it as a defensive concept for the individual in relation to domestic criminal law. It is the classic utilitarian rationale - that penal policy must serve rational ends: ${ }^{24}$

So far as the abstract theory of responsibility is concerned, an act which is necessary is not wrongful, even though done with full and deliberate intention. It is a familiar proverb that necessity knows no law: Necessitas non habet legem. By necessity is here meant the presence of some motive adverse to the law, and of such exceeding strength as to overcome any fear that can be inspired by the threat of legal penalties. The jus necessitatis is the right of a man to do that from which he cannot be dissuaded by any terror of legal punishment. Where threats are necessarily ineffective, they should not be made, and their fulfilment is the infliction of needless and uncompensated evil.

Salmond considered the classic "necessity" situations: two drowning men clinging to a plank that will not support both and which is seized by the stronger; and the " $R v$ Dudley situation" of shipwrecked and starving sailors who kill and eat their comrades. He is clear as to the legal and moral positions - the actors are "in law guilty of murder itself; but the clemency of the Crown will commute the capital sentence to a short term of imprisonment". ${ }^{25}$ So the necessity-driven acts retain their illegal character but may be wholly or partly excusable.

So far, Salmond has maintained the distinction between "justification" and "excuse", the modern literature on which is considerable. ${ }^{26}$ A good general statement is found in the 1985 Canadian case of Perka $v$ R, where Dickson J said: ${ }^{27}$

Conceptualized as an "excuse", however, the residual defence of necessity is, in my view, much less open to criticism ... The objectivity of the criminal law is preserved; such acts are still wrongful, but in the circumstances they are excusable. Praise is indeed not bestowed, but pardon is, when one does a wrongful act under pressure which, in the words of Aristotle in The Nicomachean Ethics ... "overstrains human nature and which no one could withstand".

Another commentator throws light on the historical development of the justificatory and excusatory defences respectively. Donald Horowitz explains: ${ }^{28}$

24 Salmond Jurisprudence, above n 8, 406. The Oxford Dictionary of Quotations, above n 2, 526, attributes the maxim "Necessitas non habet legem" to Publilius Syrus who lived in the first century BC.

25 Ibid, 408

26 See for example, K Greenawalt "The Perplexing Borders of Justification and Excuse" (1984) 84 Colum L Rev 1897.

27 Perka $v$ R (1985) 14 CCC (3d) 385, 398 (SCC) Dickson J. The passage was cited with approval in New Zealand in Kapi v MOT [1992] 1 NZLR 227, 230 (HC) Jeffries J. 
Justification defences evolved earlier largely in connection with privileges accorded to recognized authorities to take forcible action against law-breakers. Excuse defences evolved later, in tandem with the slow growth of the idea of culpability as integral to the criminal law.

But some perplexing questions arise when the simple criminal model is extrapolated. For example, should artificial entities such as companies be afforded a similar defence? Should a company faced with bankruptcy be permitted to defend a charge of dishonest dealing on the basis of a "necessity" to save its continued existence? I anticipate a negative answer. More topically, should a State whose existence is fundamentally threatened be allowed to justify or excuse breaches of domestic or international law on the same analogy? Answers begin to become more complex.

Salmond is less clear on the justification/excuse distinction when the State is the actor motivated by necessity: 29

The civil law has little to say as to the exercise by the state of its military functions. As between the state and its external enemies, it is absolutely silent; and even as to the use of extrajudicial force within the body politic itself, as in the suppression of riots, insurrections, or forcible crimes, the law lays down no principle save this, that such force is allowable when, and only when, it is necessary. Necessitas non habet legem.

Force is "allowable" - and the same Latin maxim is summoned as for the defence in criminal matters. The writer's book on Salmond's life and times cited Salmond's formal opinion to Prime Minister Massey in 1913 that extraordinary actions contemplated by the Government to control the industrial troubles of that time "although otherwise illegal, are justified in law by the necessity of the case". I had commented that: "Here is theory come to practice: the State is justified in taking illegal action in its own defence". ${ }^{30}$

Salmond's point is that necessity justifies the illegality - it is illegal action which is justified. One of the arguments of this Paper is that to collapse the steps by which prima facie illegality is either justified or excused plays into the hands of those who would put the State permanently and unreviewably in the meta-legal posture. Is the "necessity" wand so powerful an instrument that it may retrospectively rewrite the statute book? If so, we had better see carefully who or what wields that wand, because there lies Hobbes' Leviathan. There also lies Carl Schmitt's "sovereign" with the power to "decide the exception", which we will consider in more detail in section VII below.

In the criminal law context, Stanley Yeo makes a distinction between "justificatory necessity" and "excusatory necessity", pointing out that "a plea of excuse is relevant only after it has been

28 Donald L Horowitz "Justification and Excuse in the Program of the Criminal Law" (1986) 49:3 Law and Contemporary Problems 109, 126.

29 Salmond Jurisprudence, above n 8, 142.

30 Frame Salmond: Southern Jurist, above n 10, 162. 
determined that the actor's conduct was unjustified and therefore wrong in society's eyes. After all, if the conduct was justified, there would be nothing to excuse". ${ }^{31}$

But it is the linguistic philosopher, JL Austin, Hart's friend and colleague at Oxford, to whom we owe the clearest exposition of the nuances between the justificatory and excusatory pleas in respect of "necessity". In his classic essay "A Plea for Excuses", Austin states that "in the one defence, briefly, we accept responsibility but deny that it was bad; in the other, we admit that it was bad but don't accept full, or even any, responsibility."32

In the same essay, the justification for clarity in our use of legal language is well put: ${ }^{33}$

First, words are our tools, and, as a minimum we should use clean tools: we should know what we mean and what we do not, and we must forearm ourselves against the traps that language sets us. Secondly, words are not (except in their own little corner) facts or things: we need therefore to prise them off the world, to hold them apart from and against it, so that we can realize their inadequacies and arbitrariness, and can look at the world without blinkers.

\section{SALMOND IN ACTION}

How should we relate Salmond's actions as the State's principal legal adviser in turbulent times to Salmond's legal philosophies as expressed in his writings? In her recently published and penetrating book on HLA Hart, Nicola Lacey discusses that eminent legal philosopher's role during World War II in MI5 - the organisation primarily concerned with counter-espionage. After quoting a Hart-written memorandum advocating a requirement for the compulsory carrying by all civilians of identity cards, Lacey comments that "it is a reminder ... of the extent to which even the most liberal people have to temper their civil libertarian instincts in the context of war." 34

I want in this section to discuss three episodes in which Salmond had occasion to act or advise in relation to "State necessity", with a view to seeing how practice squares with theory.

\section{A Advice to Government in the 1912-13 Industrial Disturbances}

This involved approval for the use of military personnel for the suppression of riots and the occupation of property. Salmond's opinion of 28 October 1913 advised that "all His Majesty's subjects, whether they hold any official position or not" were authorised "at common law and under

31 Stanley M H Yeo Compulsion in the Criminal Law (Law Book Company, Sydney, 1990) 6.

32 J L Austin "A Plea for Excuses" in J O Urmson and G J Warnock (eds) Philosophical Papers (3 ed, Oxford University Press, 1979) 176. The essay was first published in Proceedings of the Aristotelian Society 1956-7 (Williams and Norgate, London, 1957) ch 8.

33 Ibid, 181-182.

34 Nicola Lacey A Life of HLA Hart: The Nightmare and the Noble Dream (Oxford University Press, London, 2004) 98. 
the Crimes Act 1908" to use "such force as may be reasonably necessary to suppress riots or other forcible crimes". As for the occupation of property, an opinion of 20 November 1913 advised that the common law permitted the use of "such force ... and such other measures as are reasonably deemed necessary ... all such acts, although otherwise illegal, are justified in law by the necessity of the case". This advice would appear unexceptionable and supported by judicial authority. ${ }^{35}$

Salmond could have delved deeper than his citation of $R v$ Pinney (the Bristol riots case) ${ }^{36}$ for his proposition. Butterfield cites Glen Burgess' conclusion that "the idea that necessity could justify the abandonment of law, even the destruction of property rights, was a central principle of English common law", and also John Marsh's justification, in 1642, of Parliament's usurpation of the power to proclaim war by reference to Coke's report of the Bishop of Salisbury's Case where it is said that: "In time of necessitie, illegal acts, are made legall: and things utterly against law justifiable." 37

In his earliest statement of principles, Salmond viewed rebellion and riot as akin to war waged by the State - and, therefore, as subject to the maxim inter arma leges silent: ${ }^{38}$

[T] he repression of rebellions, or of riots that do not rise to the dignity of rebellions, is war between a state and a group of individuals who, though to some extent associated for warlike purposes, cannot be said themselves to constitute a state.

\section{B A Practical Problem for Necessity and Legality}

A small but practical problem landed in the lap of the Solicitor-General in 1917. EW Gabites had been made a prisoner of war by Germany and, as a condition of his release, had given his parole not to take part in military operations against Germany. The question arose whether on his return to New Zealand he was subject to military service under the comprehensive terms of the New Zealand Statute drafted by Salmond. The Solicitor-General's opinion was theoretically uncompromising but practically sympathetic: ${ }^{39}$

The fact that this man while a prisoner of war gave his parole not to take part in military operations against the German Empire does not ... affect his obligation of military service under the Military Service Act 1916 ... He should be permitted to amend his notice of appeal so as to appeal on the ground

35 Frame Salmond: Southern Jurist, above n 10, 156 and 162.

$36 \quad R v$ Pinney (1832) 37 RR 599.

37 Butterfield, above n 1, 54-55. The references are to Glen Burgess Absolute Monarchy and to John Marsh, An Argument etc..., see Butterfield's footnote 114.

38 Salmond First Principles of Jurisprudence, above n 13, 119.

39 J W Salmond "Opinion" (Crown Law Office, 27 September 1917) Opinions for Recruiting Board (19161918) (Crown Law Office, Wellington, 1918). 
of undue hardship ... on the ground that his calling up would compel him to disregard the moral obligation imposed on him by his parole.

An example perhaps of Salmond taking his own advice to "keep your head hard and your heart soft. Hardening of the heart is a disease no less serious than softening of the brain." 40 The Evening Post of 19 October 1917 records the highly pragmatic solution before the Military Service Board Mr Gabites was found "fit for home duty only". ${ }^{41}$

\section{Unauthorised Surveillance and Interference with Postal Communications in 1917}

Salmond's 1916 recommendation that powers be taken for war censorship had gone unheeded by his political superiors, but he had added that, in the meantime, the authorities "should assume without question that full power exists for the censorship of all postal and telegraphic communications whatever". The records show that as early as 1915 Salmond had advised the Police to censor "anarchist literature": 42

I think that the best course ... is to arrange with the Post Office to have all correspondence addressed to Josephs ... stopped and examined. It may be that such examination will show that Josephs is an active agent of the I.W.W. or of other anarchist and criminal organisations.

The Attorney-General of the day, Herdman, subsequently defended, on the basis of necessity, Salmond's instruction to the Military Censor on 15 December 1916 that the post box of the Protestant Political Association be monitored and controlled. Having recited the dangers to the State, Herdman asked Members of Parliament: "why, then, should the State not step in for the purpose of preventing the circulation of literature which was offensive to a very large section of this community holding certain religious beliefs?"43

The 1917 "Post Office Inquiry" - known as the "Bishop Inquiry" after its Chairman - raised issues similar to those of the current controversy in the United States concerning unwarranted surveillance. The Bush administration's domestic spying program, and in particular its use of unwarranted electronic surveillance of persons within the United States, was defended by the Department of Justice's communication to Congress dated 22 December 2005. The administration's officials argued that the restrictions imposed by the Foreign Intelligence Surveillance Act (FISA) 1978 were superseded by the circumstances of the "war on terror" - this was an explicit reliance on "State necessity".

40 Salmond 'My Son' said the Philosopher, above n 23.

41 (19 October 1917) Evening Post Wellington 6.

42 Solicitor-General Salmond to Police Department (20 October 1915) in Opinions - Police Department 1913 1926 (Crown Law Office, Wellington). The reference to "IWW" is to the Industrial Workers of the World, known colloquially as "the Wobblies".

43 Frame Salmond: Southern Jurist, above n 10, 175-177. 
A group of "scholars of constitutional law and former government officials" responded to the Department of Justice's letter as follows: ${ }^{44}$

[T]he DOJ letter fails to offer a plausible legal defence of the NSA domestic spying program. If the administration felt that FISA was insufficient, the proper course was to seek legislative amendment ... One of the crucial features of a constitutional democracy is that it is always open to the President - or anyone else - to seek to change the law. But it is also beyond dispute that, in such a democracy, the President cannot simply violate criminal laws behind closed doors because he deems them obsolete or impracticable.

In 1917, Salmond's former student and protégé, later Ostler J, acting as counsel for the Protestant Political Association before the Bishop Inquiry, had accused Salmond of acting "above the law, like a dictator" and of preferring "the secret and illegal method". There was surely an ironic tone in the finding of the Inquiry that: ${ }^{45}$

Mr Salmond will no doubt note the fact for his future guidance that Mr Ostler considers his practice of law considerably weaker than his knowledge, and apparently chides him for attempting to act as master or dictator, instead of a public servant. I leave it at that.

\section{STATE LEGALITY IN WAR}

Six of Salmond's ten years as the principal legal adviser to the New Zealand Government were during or immediately following total world war in which the executive branch of government was accorded powers to regulate all aspects of the national life without reference to Parliament or regard for existing statute law. As Solicitor-General Salmond told the Supreme Court in 1917: "We are living at present largely under a despotic Government". ${ }^{46}$

The Ciceronian maxim inter arma leges silent found its way into Appendix III of Salmond's Jurisprudence with this explanation by the author: ${ }^{47}$

This maxim has a double application: (1) As between the state and its external enemies, the laws are absolutely silent ... (2) Even as regards the rights of subjects and citizens, the law may be put to silence by necessity in times of civil disturbance ... Extrajudicial force may lawfully supersede the ordinary process and course of law, whenever it is needed for the protection of the state and the public order against illegal violence.

44 Curtis Bradley, David Cole, Walter Dellinger, Ronald Dworkin, Richard Epstein, Philip B Heymann and others "On NSA spying: a letter to Congress" (9 February 2006) New York Review of Books New York 44.

45 "Auckland Post-Office Inquiry: Report of Commissioner; together with Minutes of Evidence" [1917] AJHR F-8.

46 Taratahi Dairy Co Ltd v Attorney-General [1917] NZLR 1, 9 (SC).

47 Salmond Jurisprudence, above n 8, 535. 
It is possible to admire the dissent of Lord Atkin in Liversidge $v$ Anderson without assuming the naïve belief that wartime conditions have no effect on the administration of justice and the balance struck by courts between national needs and individual freedoms. Lord Atkin's stirring call was that "[i]n this country, amid the clash of arms, the laws are not silent. They may be changed, but they speak the same language in war as in peace." 48

But Lord Atkin's lonely voice in the case, and the tenor of the speeches of the other Law Lords, indicate the aspirational character of the dissent. Lord Macmillan, for example, said: ${ }^{49}$

But in a time of emergency when the life of the whole nation is at stake it may well be that a regulation for the defence of the realm may quite properly have a meaning which, because of its drastic invasion of the liberty of the subject the courts would be slow to attribute to a peace time measure.

Holmes $\mathrm{J}$ - ever the realist - made this candid admission: ${ }^{50}$

When a nation is at war many things that might be said in time of peace are such a hindrance to its effort that their utterance will not be endured so long as men fight and that no court could regard them as protected by any constitutional right.

It is a feature of the political structure of many societies that the powers accorded to leaders and chiefs is greater in war, or in war-like circumstances, than in times of peace. It has recently become possible to read the minutes of Prime Minister Churchill's war Cabinet meetings, and the candour with which proposals to shackle, and even shoot, German prisoners in retribution for alleged German ill-treatment are made - in the face of opposition by the Dominion Prime Ministers - is startling to the peace-time reader. ${ }^{51}$

War and national danger are triggers for the enlargement of executive power. It is not surprising therefore that political leaders have well-developed antennae for the opportunities they represent. Fortunately, war is a relatively restricted category with obvious features. One of the many disturbing aspects of the so-called "war on terror" is that, as Mark Tushnet has observed: ${ }^{52}$

48 Liversidge v Sir John Anderson [1942] AC 206, 244 Lord Atkin.

49 Ibid, 251 Lord Macmillan. Lord Macmillan quoted from Lord Atkinson's speech in Rex v Halliday [1917] AC 260. Lord Shaw's dissent in that case was as solitary as Lord Atkin's a World War later.

50 Schenck $v$ US (1919) 49 US 47, 52 Holmes J.

51 See for example meeting of 12 October 1942, CAB 195/1 - transcript available online at www.nationalarchives.gov.uk (accessed 1 October 2007).

52 Mark Tushnet "Emergencies and the Idea of Constitutionalism" in Mark Tushnet (ed) The Constitution in Wartime (Duke University Press, Durham (NC), 2005) 45. 
It is, perhaps, more like a condition than a war ... Suspending legality during a time-limited war is one thing. Suspending it during a more or less permanent condition is quite another. The latter is the end of the rule of law itself.

\section{NECESSITY AT INTERNATIONAL LAW}

The International Law Commission's long-considered Draft Articles and Commentary on Responsibility of States for Internationally Wrongful Acts (adopted in 2001) recognise that the wrongfulness of some acts of a State may be precluded by special circumstances. "Self-defence" (Article 21), "Countermeasures" (Article 22), "Force majeure" (Article 23), "Distress" (Article 24), and "Necessity" (Article 25) are the five circumstances identified.

As to "Necessity", Draft Article 25 proposes the following:

1. Necessity may not be invoked by a State as a ground for precluding the wrongfulness of an act not in conformity with an international obligation of that State unless the act:

(a) is the only means for the State to safeguard an essential interest against a grave and imminent peril; and

(b) does not seriously impair an essential interest of the State or States towards which the obligation exists, or of the international community as a whole.

2. In any case, necessity may not be invoked by a State as a ground for precluding wrongfulness if:

(a) the international obligation in question excludes the possibility of invoking necessity; or

(b) the State has contributed to the situation of necessity.

The negative structure of the Article is noteworthy: "Necessity may not be invoked ... unless". The ILC's commentary on the draft article states that: ${ }^{53}$

the term "necessity" is used to denote those exceptional cases where the only way a State can safeguard an essential interest threatened by a grave and imminent peril is, for the time being, not to perform some other international obligation of lesser weight or urgency ... It arises where there is an irreconcilable conflict, between an essential interest on the one hand and an obligation of the State invoking necessity on the other. These special features mean that necessity will only rarely be available to excuse nonperformance of an obligation and that it is subject to strict limitations to safeguard against possible abuse.

Echoing JL Austin's plea for care in the choice of language in the distinction between justificatory and excusatory necessity, Hugh Thirlway has proposed that a possible view of the

53 James Crawford The International Law Commission's Articles on State Responsibility (Cambridge University Press, Cambridge, 2002) 178. 
Commission's "circumstances precluding wrongfulness" is that "a prima facie unlawful act in these circumstances remained unlawful, but some of the consequences that would otherwise attach to it would not do so." 54

Could France have argued that the bombing of the Rainbow Warrior by its agents in Auckland Harbour and the killing of a crew member was either justified, or wholly or partly excused, on the basis of "State necessity"? The question only has to asked to be dismissed as falling well outside the terms of Draft Article 25. A more serious question might have arisen in respect of the subsequent issue whether the agents responsible for the outrage should have been prematurely repatriated to France from the concessional imprisonment on the island of Hao, in breach of the terms of the agreement, on the basis of alleged "medical emergency".

The question whether a breach of an international legal obligation is justified, or only wholly or partly excused, by "necessity" has the appearance of being merely academic. However, an important practical point is at stake: the answer establishes the posture of the breaching State. The "justification" approach lifts the breaching State above the normative system. The "excusatory" approach puts the breaching State to a "plea in mitigation" at the bar of international law and opinion.

As Friedrich Meinecke has observed, "international law and raison d'etat stand in natural opposition to one another. International law wishes to restrict the sway of raison d'etat." 55 We should try to defend the pass of the "rule of law" against the claims of "necessity", whether advanced in the criminal context by individual defendants, or by the State and its officials in derogation of public law, or by States in pursuit of "national interest" in disregard of international obligations. That defence will be assisted by maintaining wherever possible the distinction between the "justificatory" and "excusatory" uses of "necessity", and in either case by starting from the premise that there has been a breach of law.

\section{CARL SCHMITT AND EXCEPTIONALISM}

The pro-Nazi legal academic Carl Schmitt opened his "Political Theology" with the statement that "[s]overeign is he who decides on the exception". 56

His translator George Schwab explains in his introduction that Schmitt focused his attention on crises in a State's existence, and on the process by which the decision is made that extra-legality is justified. Who decides when an "exception" or "state necessity" is at hand and what should be done,

54 Hugh Thirlway "Concepts, Principles, Rules and Analogies: International and Municipal Legal Reasoning" (2002) 294 Recueil des Cours 265, 297.

55 Meinecke, above n 4, 208.

56 Carl Schmitt Political Theology: Four Chapters on the Concept of Sovereignty (trans George Schwab, MIT Press, Cambridge (Mass), 1985). First published 1922, revised 1934. 
and when the justifying circumstances have ended? Schmitt thought that these questions would lead the inquirer to the true locus of "sovereignty" in a State.

Schmitt's compatriot Otto Hinze who, in contrast to Schmitt, rejected Nazi Germany after 1933, points to a difference between the "Western" and German conceptions of raison d'état: ${ }^{57}$

In the Western view, raison d'etat implies the principle of an unconditional predominance of state interests, which coexists with and is independent of the moral code of Christian, rational natural law. In the German interpretation, as expounded by Hegel ... the contrast between raison d'etat and ethical demands disappears to a certain extent, since raison d'etat is seen as belonging to a vast process of history, which in turn is interpreted as the working out of divine reason. Consequently, there is no sharp distinction between power and justice; and ethicized power and right have their place in the divine order.

In 2003, in the case $A v$ Secretary of State, the House of Lords considered the validity of certain extraordinary measures taken by the United Kingdom Government following the terrorist attacks in the United States on 11 September 2001. Their Lordships were called upon to determine whether the Government's conclusion that there was a "public emergency threatening the life of the nation" could be reviewed by the Court. The majority concluded that review was not appropriate. Lord Bingham said that: ${ }^{58}$

great weight should be given to the judgment of the Home Secretary, his colleagues and Parliament on this question, because they were called on to exercise a pre-eminently political judgment. It involved making a factual prediction of what various people around the world might or might not do, and when (if at all) they might do it, and what the consequences might be if they did ... The more purely political (in a broad or narrow sense) a question is, the more appropriate it will be for political resolution and the less likely it is to be an appropriate matter for judicial decision ...

Although we may be entering a testing time for the control of "exceptionalism" and derogations from human rights provisions, there are some signs of recognition that the best stratagem might be openly to acknowledge the need for emergency powers and derogations but to provide mechanisms requiring reporting on the measures taken. For example, the International Covenant on Civil and Political Rights limits the rights which may be derogated from and requires a derogating state to report the circumstances to the Secretary-General of the United Nations. ${ }^{59}$

The answer given to the question "who decides on the exception?" will tell us whether the State is "above the law", functioning in what we must call a "meta-legal" universe, or whether it is bound by a law which nevertheless justifies or excuses illegal acts in rare, meritorious and proportional

57 Otto Hinze The Historical Essays of Otto Hinze (ed Felix Gilbert, Oxford University Press, New York, 1975) 375.

58 A v Secretary of State for the Home Department [2005] 2 AC 68, 102 Lord Bingham.

59 International Covenant on Civil and Political Rights (16 December 1966) 999 UNTS 171, art 4. 
circumstances. In short, the apparently frivolous question turns out to involve nothing less than an acid test for the "rule of law".

\section{SUMMING UP}

Sir John Salmond's amusement at reading his own obituary in 1917, when the death of his father - another Professor Salmond - was confused by a British newspaper with his own, shows the impish side of his character: "Meredith, I never expected to read my own death notices". He would have found humour also in wildly inconsistent contemporary and posthumous characterisations of his national identity. He is described as an "English" (and even an "Australian") jurist. Pictures from the Washington Disarmament Conference in 1920-21 variously caption him as "Aristide Briand" (the French leader), and "Sir Maurice Hankey" (Secretary to the British Cabinet). An American commentator at the Washington conference captured Salmond's anonymity in this way: ${ }^{60}$

He is what is sometimes styled an effective man. Publicly he is a vacuum; officially he is steady, four cylindrical, all-firing, pneumatic shod - the sort of man you don't notice, so to speak, until he is absent, in the same way you never notice your tyre until it goes flat.

It is interesting to note that Neil Duxbury, in his recent and illuminating survey of "English Jurisprudence between Austin and Hart" explains on definitional grounds his sparing attention to Salmond as a legal thinker, and so gives us back our distinguished jurist: ${ }^{61}$

John Salmond - born and educated partly in England, but a New Zealander for most of his life produced at the turn of the twentieth century a treatise which would become something of a classic in the common-law world and which, very much in the Austinian spirit, carefully distinguished legal rights in a strict and in a wider sense.

I should end by returning to the task of reconciling the several attitudes to the question of State power shown in the life and work of Salmond. The expedience and authoritarianism of his SolicitorGeneralship; the readiness to control executive power as a Judge; ${ }^{62}$ and the Hobbesian character of his academic writing.

What I think we are obliged to say is that Sir John Salmond understood the importance of different roles in the world of law and the need for each role to be played faithfully. For the Solicitor-General, it is advisor to the executive branch which must govern, and in war prevail; for His Majesty's Judge, it is the interpretation and application of law with impartiality even if the interests of the executive branch are affected; for the legal thinker and writer, it is the rigorous

60 CA Player Arms - And the Men (Detroit News Reprints, Detroit, 1922) 58.

61 Neil Duxbury "English Jurisprudence between Austin and Hart" (2005) 91 Va L Rev 1, 7.

62 See for example the bold and novel use of the injunction against a Minister of the Crown in Park $v$ The Minister of Education [1922] NZLR 1208 (SC), or the resistance to legislative privative clauses seen in New Zealand Waterside Workers' Federation v Frazer [1924] NZLR 689 (SC). 
intellectual analysis of fundamental concepts wherever that leads. Each of the roles had different requirements to which Salmond responded with boldness and skill. He should be allowed to rest his own defence: "negative virtues count for little in the celestial ledger. What the Recording Angel wants to know is what you did on this planet, not what you didn't." 63

\section{EPILOGUE}

The above paper was presented to the "Salmond Symposium" at Victoria University of Wellington in August 2006. A few weeks later I was asked by the Government of the Cook Islands to advise on a situation which had arisen where the direct statutory authority for the expenditure of public money had expired and a clear provision in the Constitution prevented the calling of Parliament to consider appropriations until all election petitions had been heard. The difficulties in convening courts to sit, in some cases in outer islands, meant that several weeks would elapse before Parliament could meet. I was informed that there was a real prospect of a break-down of essential services with serious damage to the people, and to the international credit-worthiness and standing of the Cook Islands, unless authority to maintain expenditure for "core-services" could be found until Parliament met.

Legal opinions commissioned by the Crown's advisers will in most circumstances remain confidential. On rare occasions, however, and with the consent of the Law Officers, such opinions may be made public. Following the making of a Proclamation by the Queen's Representative on 17 November 2006, the appended opinion was tabled in the Cook Islands Parliament, so becoming a public document. ${ }^{64}$ It is offered as a practical example of the circumstances which may call for consideration of the "necessity" doctrine and for the application of the principles formulated in the Mitchell case. The expenditure authorised by the Proclamation was not challenged before the Courts of the Cook Islands and was subsequently confirmed and validated by the Parliament of the Cook Islands in the Appropriation Act 2006, No 5, passed on 15 December, 2006.

63 'My Son' Said the Philosopher, above n 23, 1920.

64 Published in (18 December 2006) Cook Islands News, Rarotonga. Also published electronically by the Cook Islands Government at http://www.mfem.gov.ck. 


\section{APPENDIX}

Tuesday 17 October 2006

Dear Mr McFadzien,

I have been asked to provide an opinion for the assistance of the Financial Secretary to the Cook Islands Government and for the Ministers to whom he is responsible.

\section{The Situation}

1.1. The following situation is reported to me by officials and yourself:

1. That the apparent authorisation for expenditure for core government activity in the Cook Islands provided by Article 70 (3) (a) of the Constitution will come to an end with the exhaustion of an amount equal to three-twelfths of the sum appropriated in the preceding financial year together with the unexpended balance from the preceding year.

2. That the Cook Islands Government Account is in a position comfortably to meet all normal and necessary government expenditure beyond that date.

3. That delays caused by the unprecedented number of election petitions and the difficulties of hearing them at several venues mean that, as a consequence of Article 29(2) of the Constitution, Parliament will not meet until November and will not be capable of consenting to new appropriations until after that date.

4. That in the intervening period authorisation will be lacking to meet the wages, salaries and other expenditures required to run the core government services of health, education, police, customs, transport, and so on, unless there is "caretaker" bridging authorisation for expenditure until the passage of an Appropriation Bill by the new Parliament.

5. That individual hardship throughout the state services and the wider Cook Islands community, disruption of the delivery of core government services, and international harm to the reputation and credibility of the Cook Islands are real and imminent possibilities if bridging authorisation is not available.

\section{The requirement for Appropriation}

2.1. Article 70 (1) of the Constitution of the Cook Islands provides that:

All expenditure from the Cook Islands Government Account, or from any other public fund or account shall be in accordance with an Appropriation Act unless otherwise authorised or permitted by any other enactment.(emphasis added)

A question arises whether the proviso intended that authorisation and permission could come only from an Act of Parliament, or whether it contemplates that other forms of subsidiary legislation could meet the requirement in appropriate circumstances.

\subsection{The term "Enactment" is specifically defined in Article 1 of the Constitution:}

"Enactment" means any Act of the Parliament of the Cook Islands, any Ordinance, any Act of Parliament of New Zealand in force in the Cook Islands, and any Proclamation, order, regulation, or rule, or any Islands Council Ordinance or bylaw. (emphasis added) 
2.3. The term "Act" is, in the same Article, defined much more jealously:

"Act" means an Act of the Parliament of the Cook Islands.

2.4. A survey of the use of the two expressions in the Constitution reveals that both are employed by the drafters, who must be presumed to have used them with the precision made available by the definitions. It should be presumed that where the Constitution confers powers to do something "by Act" it intends that only an Act of Parliament will suffice, but where it confers powers to do something "by enactment" it contemplates that subsidiary legislative instruments, such as Regulations and Proclamations may be employed in appropriate circumstances.

\section{Use of expressions "Enactment" and "Act" in the Constitution}

3.1. In fact, study of the Constitution shows that its drafters understood the distinction between "Act" and "Enactment" and used the terms with precision - sometimes in the same Article - as in instances 10 and 12 below.

1. Art.20. The Secretary of the Cabinet to be appointed "in such manner as shall be prescribed by Act".

2. Art.27(3). Electoral provisions "shall be as prescribed by Act".

3. Art.28B(3). "An Act may..." modify the definition of "Crown servant".

4. Art.36(5). "Subject to the provisions of this Article, the privileges of Parliament...may be determined by Act".

5. Art.48(2). The Land Division of the High Court "shall have such other jurisdiction as may be conferred on it by enactment".

6. Art.60(2). Setting out the circumstances for appeals to the Court of Appeal, "except where under any Act a judgment of the High Court is declared to be final". And Article 60(3), "subject to any limitations as may be prescribed by Act".

7. Art.62(3) in relation to Justices of the Peace, "An Act shall prescribe..."

8. Art.65 providing the rule of construction, "every enactment shall be so construed..."

9. Art.66A giving the force of law to custom, "until such time as an Act otherwise provides".

10. Art.71(3) in relation to Audit, the Public Expenditure Committee is to be appointed in a manner which "shall be prescribed by Act". But see Art.71(4) providing that the PEC "shall have such other functions ....as shall be provided by enactment".

11. Art.72(2) in relation to the Public Service, declaring that "An Act shall provide for the administration and regulation of the Cook Islands Public Service.."

12. Art.73(6) in relation to the Public Service Commissioner, provides that the procedure "may be prescribed by enactment". But see Art.74(4) where his functions "shall be prescribed by Act".

13. Art.76A(3) in relation to "permanent residence" status permits that "An Act may...prescribe qualifications..."

3.2. Although there is accordingly a reputable argument to the effect that the proviso to Article 70

(1) contemplates that expenditure might be authorised other than by Act of Parliament, it is less 
clear that a Court would necessarily accept that argument. The reason for doubt is that Article 2 of the Constitution prefaces all the definitions with the words "unless the context otherwise requires". A Court could decide that the historical importance of the principle of parliamentary supervision of expenditure requires a more restrictive reading of "enactment" in Article 70 to confine it to Acts of Parliament.

3.3. The leading authority on the requirement for parliamentary appropriation is Auckland Harbour Board v. R [1924] AC 318, in which case Viscount Haldane said this for the Privy Council:

\footnotetext{
For it has been a principle of the British Constitution now for more than two centuries, a principle which their Lordships understand to have been inherited in the Constitution of New Zealand with the same stringency, that no money can be taken out of the consolidated Fund into which the revenues of the State have been paid, excepting under a distinct authorization from Parliament itself. The days are long gone by in which the Crown, or its servants, apart from Parliament, could give such an authorization or ratify an improper payment. Any payment out of the consolidated fund made without parliamentary authority is simply illegal and ultra vires, and may be recovered by the Government if it can, as here, be traced. (at pages 326-327)
}

3.4. However, the question raised by the particular drafting of Article 70(1) of the Constitution is whether the Cook Islands has, as a matter of law, adopted the principle "with the same stringency". I regard the two rival arguments as fairly evenly balanced, and much would depend on the approach taken by the Court to interpretation of the Constitution.

3.5. The present Cook Islands situation is far from that in the Zimbabwe case of Foroma v. Smith [1997] 4 LRC 174. In Zimbabwe the unauthorised expenditure was for what the Court described as a "corrupt and illegal government housing scheme". It is also worthy of notice that section 102 of the Constitution of Zimbabwe insisted that no moneys could be withdrawn from the consolidated revenue except under authorisation "by the Constitution or by Act of Parliament". That wording eliminated the ambiguity of the Cook Islands provision.

3.6. I note also that Article 70 (3A) contemplates that where expenditure in excess of the limits prescribed in Article 70 (3) has occurred, it may be reported to Parliament which "may by Act validate the whole or any part of that expenditure".

\section{Necessity as Justification}

4.1. The judgment of Haynes P. in the Caribbean case of Mitchell v. DPP [1986] LRC (Const) 35 has achieved added importance in Pacific common-law jurisdictions because of its approval by Sir Maurice Casey, the President of the Fiji Court of Appeal, in Republic of Fiji v. Prasad [2001] 2 LRC 743. Although Prasad was of course about the legal survival of the 1997 Fiji Constitution following the coup, it also considered the circumstances in which "necessity" might justify state officials in taking extra-constitutional actions. In Prasad, Sir Maurice Casey cited the judgment of Haynes P with approval, and specifically this passage in relation to "necessity":

I would lay down the requisite conditions to be (1) an imperative necessity must arise because of exceptional circumstances not provided for in the Constitution, for immediate action to be taken to protect or preserve some vital function of the State; (2) there must be no other course of action reasonably available; (3) any such action must be reasonably necessary in the interests of peace, order, and good government; but it must not do more than is necessary or legislate beyond that; (4) it must not 
impair the just rights of citizens under the Constitution; (5) it must not be one the sole effect and intention of which is to consolidate or strengthen the revolution as such. (emphasis added)

4.2. President Haynes went on:

"It is for this court to pronounce on the validity (if so) of any unconstitutional action on the basis of necessity, after determining as questions of fact, whether or not the above conditions exist... Such validation will not be a once-for-all validation so to speak, it will be a temporary one, being effective only during the existence of the necessity. If and when this ends, the right constitutional steps must be taken forthwith, that is, within a reasonable time"

4.3. I do not believe that it is far-fetched to regard the impending failure of government supply for basic services in the Cook Islands as capable of triggering the "necessity" doctrine. Such an occurrence could be just as significant to the "peace, order, and good government" of the Cook Islands as external threat, internal disorder, or natural disaster. Furthermore, when the present circumstances are placed alongside the test laid down by President Haynes in Mitchell as set out at paragraph 4.1 above, they will be found to be substantially congruent in the following ways:

- $\quad$ There is "an imperative necessity" due to "exceptional circumstances".

- A "vital function of the State" is imperilled - the provision of core public services.

- "No other course of action" is available to authorise bridging expenditure.

- $\quad$ The action proposed is "reasonably necessary" for good government.

- It does "no more than necessary" to save the situation.

- $\quad$ It does not "impair the just rights" of citizens under the Constitution.

- It expressly contemplates confirmation of the action by Parliament.

\section{Proposed Course of Action}

5.1. It is not in my view desirable that an official such as the Financial Secretary be left to take a necessity-based decision in contravention of the Constitution. That fundamental document does not repose discretions of that order in individual officials. It would create bad precedent for the future and open the officials concerned to public, and perhaps judicial, criticism.

5.2. The course suggested here is that a mechanism contemplated by the Constitution, involving responsible Ministers together with the Queen's Representative acting as a check, be activated to authorise a limited and conditional bridging expenditure from the Cook Islands Government Account, until Parliament can meet and consider a measure confirming and continuing the appropriations in the more usual manner.

5.3. It is suggested that a Proclamation be made by the Queen's Representative pursuant to Article 12(2) of the Constitution, following a meeting of the Executive Council summoned under Articles 24 and 25 of the Constitution. An alternative might be the making of Regulations, following the same process and to the same effect, pursuant to section 69 of the Ministry of Finance and Economic Management Act 1995-96.

5.4. Although, as concluded in paragraph 3.2. above, there is an element of doubt whether a Court would treat a Proclamation authorising expenditure as constitutionally permissible, there is a 
reputable argument that the terms of Article 70 (1) do, on their face, contemplate that result. More importantly, underlying the proposal is the concept of "necessity" as an ultimate justification. I have taken the liberty of attaching as an Appendix a draft of a possible Proclamation. I should stress that great care should be taken with the drafting of this document, which must expect judicial scrutiny, and should also provide a carefully limited and considered constitutional precedent for the future. In particular, it is important that the clear "necessity" of the situation be demonstrable to any Court which may be called upon to review the Proclamation. The more uncertain it is that the existing Article 70 (3) (a) authorisation has, or will imminently, "hit the wall", the less compelling will be the argument of "necessity".

5.5. I have studied the terms of the Ministry of Finance and Economic Management Act 1995-96 and note that section 32 of that Act provides that:

"No expense or liability shall be incurred by the Crown unless the expenditure ....is in accordance with Article 70 of the Constitution..."

That formula merely returns us to the ambiguity of Article 70 itself.

5.6. In summary, the Cook Islands Government appears to be faced with a real problem to which the Constitution provides no explicit answer. Although the course proposed is unusual, there is a serious argument that it is constitutionally justified by the plain terms of Article 70(1) and/or by the doctrine of necessity. It is important to bear in mind, however, that the justification of "necessity" is an exceptional one. I have not before proposed it in 25 years of advising in the Cook Islands and other jurisdictions in the South Pacific. Its success if challenged before the Courts, as well as the bar of public opinion, will require clear demonstration of the grave and imminent danger to the State and its people, and the absence of any other means of averting harm to the State and people of the Cook Islands.

I trust that this may be of assistance to the Financial Secretary and Ministers of the Cook Islands Government. I am of course ready to offer further explanation and advice as may be required. I am sure that you will wish to supply a copy of this opinion to the Solicitor-General also, as the Government's principal legal adviser.

Yours sincerely,

Dr Alex Frame LL.D

Barrister of the High Courts of the

Cook Islands and New Zealand 
